\title{
Karateristik Pasien Karsinoma Ovarium Berdasarkan Gejala Klinis, Penyakit Penyerta, Komplikasi, dan Usia di Ruang Rawat Inap RSUD Al- Ihsan Bandung
}

\author{
Raden Ajeng Wahyu Ayuadiningsih*, Siti Annisa Devi Trusda
}

Prodi Pendidikan Kedokteran, Fakultas Kedokteran, Universitas Islam Bandung, Indonesia.

*rdnajngwahyu@gmail.com, siti.anisa@unisba.ac.id

\begin{abstract}
Ovarian carcinoma is a primary malignant process that occurs in the ovaries. This disease is commonly found in postmenopausal women with various clinical symptoms, comorbidities, and complications. This study aims to determine how ovarian carcinoma is based on the characteristics of clinical symptoms, comorbidities, complications, and age in patients at Al-Ihsan Hospital Bandung for the period January 2018-December 2019. The population in this study were patients with ovarian carcinoma at Al-Ihsan Hospital Bandung. . The sampling technique used in this study was the total sampling technique, covering all patients with ovarian carcinoma at RSUD Al-Ihsan Bandung for the period 2018-2019. The results showed that the number of patients hospitalized in RSUD Al-Ihsan Bandung for no longer than 5 days was $72.5 \%$. In addition, the number of ovarian carcinoma patients at Al-Ihsan Hospital Bandung with the most clinical symptoms detected, namely anemia by $47.83 \%$, comorbidities, namely uterine myoma and gastritis by $40.00 \%$, complications namely sepsis and pleural effusion by $33.33 \%$. , and most have an age between $30-50$ years at $47.50 \%$.
\end{abstract}

Keywords: Ovarian Carcinoma, Clinical Symptoms, Complementary Symptoms, Complications, and Age.

Abstrak. Karsinoma ovarium adalah proses keganasan primer yang terjadi pada ovarium. Penyakit ini umumnya dijumpai pada wanita usia pasca menopause dengan berbagai macam gejala klinis, penyakit penyerta, dan komplikasi yang timbul. Penelitian ini bertujuan untuk mengetahui bagaimana karsinoma ovarium berdasarkan karateristik gejala klinis, penyakit penyerta, komplikasi, dan usia pada pasien di RS AlIhsan Bandung periode Januari 2018 - Desember 2019. Populasi dalam penelitian ini adalah pasien penderita karsinoma ovarium di RS Al-Ihsan Bandung. Teknik penentuan sampel yang digunakan dalam penelitian ini yaitu teknik total sampling, mencangkup seluruh pasien penderita karsinoma ovarium di RSUD Al-Ihsan Bandung periode 2018-2019. Metode penelitian yang digunakan dalam penelitian ini adalah metode deskriptif. Hasil penelitian menunjukan bahwa jumlah pasien yang dirawat inap di RSUD Al-Ihsan Bandung paling lama kurang dari 5 hari sebesar 72,5\%. Selain itu jumlah pasien karsinoma ovarium di RSUD Al-Ihsan Bandung yang paling banyak terdeteksi gejala klinis yaitu anemia sebesar $47,83 \%$, penyakit penyerta yaitu mioma uteri dan gastritis sebesar $40,00 \%$, komplikasi yaitu sepsis dan efusi pleura sebesar 33,33\%, serta paling banyak memiliki usia antara 30-50 tahun sebesar $47,50 \%$.

Kata Kunci: Karsinoma Ovarium, Gejala Klinis, Gejala Penyerta, Komplikasi, dan Usia. 


\section{A. Pendahuluan}

Karsinoma ovarium merupakan keganasan yang paling mematikan di bidang ginekologi. Penyakit karsinoma merupakan salah satu penyebab tingkat kematian yang tinggi di seluruh dunia. Berdasarkan data global cancer observatory (GLOBOCAN) dari international agency for research on cancer (IARC) menyebutkan bahwa pada tahun 2018 terdapat 18.078.957 jumlah kasus karsinoma baru di seluruh dunia, dengan tingkat kematian (mortalitas) sebanyak 52,85\%. Jumlah kasus karsinoma di dunia menunjukan bahwa secara keseluruhan karsinoma paling banyak menyerang pria dibandingkan wanita. Data dari GLOBOCAN menyebutkan di dunia kasus karsinoma pada pria sebanyak 52,31\% dengan tingkat kematian sebesar 56,95\%, sementara pada wanita sebesar 47,69\% dengan tingkat kematian sebesar 48,35\%. Pada tahun 2018 di Indoensia terdapat jumlah kasus karsinoma baru sebanyak 348.819 kasus di Indonesia dengan tingkat kematian sebesar 59,40\%. Jumlah kasus karsinoma di Indonesia menunjukan bahwa secara keseluruhan karsinoma paling banyak menyerang wanita dibandingkan pria, hal ini berbanding terbalik dengan data kasus karsinoma di dunia. Data GLOBOCAN menyebutkan bahwa di Indonesia kasus karsinoma pada pria sebesar 46,03\%, dengan tingkat kematian sebesar $67,37 \%$, sementara pada wanita sebesar 53,96\%, dengan tingkat kematian 52,61\%.

Data World Health Organization tahun 2018 menyebutkan bahwa angka harapan hidup (AHH) pasien karsinoma ovarium di Indonesia cenderung lebih rendah dibandingkan di dunia. Hal tersebut menunjukan bahwa AHH pasien karsinoma ovarium di Indonesia jauh lebih buruk dibandingkan dunia.

Salah satu penyebab tingginya kematian pada wanita di seluruh dunia setiap tahunnya yaitu akibat karsinoma ovarium. Secara epidemiologi, karsinoma ovarium termasuk salah satu karsinoma ginekologi dengan tingkat mortalitas yang tinggi secara global. Karsinoma ovarium adalah karsinoma primer yang berasal dari ovarium. Karsinoma ovarium merupakan penyebab kematian tertinggi pada karsinoma alat genitalia perempuan. Karsinoma ovarium tipe epitelial merupakan keganasan ovarium yang paling banyak ditemukan dan biasanya asimtomatis sampai terjadi metastase sehingga kebanyakan pasien yang datang sudah memasuki stadium lanjut. Selain itu penyakit heterogen yang diklasifikasikan ke dalam 3 jenis karsinoma ovarium diantaranya epithelial ovarium cancer, germ cell tumor, dan sex cord stromal tumors.

Pada dasarnya karsinoma tidak dapat diobati, karena sampai saat ini belum ditemukan obatnya. Akan tetapi, perkembangan karsinoma dapat dicegah, sehingga angka harapan hidup penderitanya bisa lebih lama. Pencegahan terhadap perkembangan karsinoma itu bisa dilakukan jika penderita segera melakukan pengobatan pada stadium awal dengan mengurangi faktorfaktor risiko dan mengobatinya secara efektif. Oleh karena itu, pendekteksian sejak dini sangat penting dilakukan, namun pada kenyataannya sangat sulit untuk mendiagnosis penyakit ini pada stadium awal.

Fase dari karsinoma ovarium sendiri terbagi menjadi menjadi empat stadium yaitu stadium I yaitu tumor terbatas pada ovarium, stadium II yaitu tumor pada 1 atau kedua ovarium dengan perluasan pada pelvis (below the pelvic brim) atau karsinoma pada peritoneal primer, stadium III yaitu tumor pada 1 atau kedua ovarium pada pemeriksaan sitologi dan histologi terjadi penyebaran ke luar peritoneum, pelvis atau metastasis ke nodus limfe retroperitoneal, dan stadium IV yaitu metastasis jauh diluar peritoneal.

Berdasarkan uraian latar belakang di atas, maka peneliti tertarik untuk meneliti lebih lanjut mengenai judul yaitu Karateristik Pasien Karsinoma Ovarium Berdasarkan Gejala Klinis, Penyakit Penyerta, Komplikasi, dan Usia di Ruang Rawat Inap RSUD Al-Ihsan Bandung Periode Januari 2018-Desember 2019. Tujuan dilaksanakannya penelitian ini yaitu untuk mengetahui karateristik gejala klinis, penyakit penyerta, komplikasi, dan usia pada pasien karsinoma ovarium yang menjalani rawat inap di RSUD Al-Ihsan Bandung periode 2018-2019.

Beberapa karateristik pada pasien karsinoma ovarium dianatarnya :

1. Gejala Klinis

Gejala klinis adalah gambaran objektif dari suatu kondisi penyakit atau kelainan medis. Gejala klinis pada karsinoma ovarium stadium awal biasanya jarang terlihat. Beberapa gejala yang masuk dalam gejala klinis pada pasien karsinoma ovarium diantaranya kista ovarium, anemia, pendarahan uterus abnormal (PUA), ileus paralitik, retensi urine. 
2. Penyakit Penyerta

Penyakit penyerta yaitu penyakit lain yang timbul atau dapat dialami pada penderita karsinoma ovarium. Penyakit penyerta pada pasien karsinoma ovarium diantaranya mioma uteri, gastritis, dan TBC paru.

3. Komplikasi

Komplikasi yaitu suatu efek samping yang ditimbulkan karena adanya karsinoma ovarium. Penyakit penyerta pada pasien karsinoma ovarium diantaranya mioma uteri, gastritis, dan TBC paru. Sementara gejala yang termasuk komplikasi pada pasien karsinoma ovarium diantaranya adhesi matur, sepsis, acute kidney injury (AKI), efusi pleura, dan congestive heart failure (CHF).

4. Usia

Salah satu faktor risiko pada karsinoma ovarium diantaranya didasarkan atas usia. Usia merupakan faktor yang paling penting dalam menentukan risiko keganasan. Karsinoma ovarium dapat terjadi pada semua golongan umur, bahkan balita dan anak-anak. Karsinoma ovarium dapat menyerang pada umur yang lebih muda dibandingkan dengan karsinoma jenis lainnya, biasanya karsinoma ovarium menyerang wanita mulai dari usia muda berkisar antara berumur sekitar $<30$ tahun. Risiko karsinoma ovarium meningkat seiring dengan bertambahnya usia, karsinoma ovarium meningkat pesat setelah wanita berusia antara 30-50, sedangkan usia puncak berkisar pada usia antara 51-70 tahun. Sementara pada usia > 70 tahun, keganasan karsinoma ovarium secara bertahap menurun. Secara umum, penuaan memungkinkan perpanjangan waktu untuk menyebabkan perubahan genetik secara acak dalam epitel permukaan ovarium.

\section{B. Metode Penelitian}

Rancangan penelitian ini adalah kuantitatif dengan desain deskriptif obervasional dengan metode survey. Populasi terjangkau pada penelitian ini adalah seluruh pasien penderita karsinoma ovarium yang dirawat inap di RSUD Al-Ihsan Bandung periode 2018-2019. Sampel dalam penelitian ini yaitu pasien penderita karsinoma ovarium dan memiliki data rekam medis yang lengkap di RSUD Al-Ihsan Bandung periode 2018-2019 berjumlah 40 pasien. Nalsiis data yang digunakan yaitu analsisi deskriptif dengan berdasarkan data rekam medis pasien karsinoma ovarium yang dirawat inap di RSUD Al-Ihsan Bandung periode 2018-2019.

\section{Hasil Penelitian dan Pembahasan}

\section{Karateristik Pasien Karsinoma Ovarium Rawat Inap di RSUD Al-Ihsan Bandung}

Di bawah ini akan disajikan data pasien karsinoma ovarium di RSUD Al-Ihsan Bandung periode 2018-2019 berdasarkan karateristik lama rawat inap sebagai berikut:

Tabel 1. Pasien Karsinoma Ovarium Berdasarkan Lama Rawat Inap

\begin{tabular}{|c|c|c|c|c|}
\hline No & Keterangan & Kasilifikasi & $\mathbf{N}$ & $\%$ \\
\hline \multirow[t]{3}{*}{1.} & \multirow[t]{3}{*}{ Rawat Inap } & $<5$ Hari & 29 & $72,5 \%$ \\
\hline & & 5 - 10 Hari & 11 & $27,5 \%$ \\
\hline & & $>10$ Hari & - & \\
\hline \multirow[t]{2}{*}{2.} & \multirow[t]{2}{*}{ Status Pasien } & Hidup & 39 & $97,5 \%$ \\
\hline & & Meninggal & 1 & $0,25 \%$ \\
\hline
\end{tabular}

Sumber : RS Al-Ihsan Bandung

Berdasarkan tabel 1 di atas menunjukan bahwa jumlah pasien karsinoma ovarium yang dirawat inap di RSUD Al-Ihsan Bandung periode 2018-2019 berjumlah 40 pasien. Jumlah pasien yang dirawat inap di RSUD Al-Ihsan Bandung paling lama kurang dari 5 hari sebesar 72,5\%. Sementara dari 40 pasien karsinoma ovarium yang dirawat inap di RS Al-Ihsan Bandung periode 2018-2019 terdapat pasien yang meninggal dunia sebesar 0,25\% (kurang dari 48 jam pada saat rawat inap). 


\section{Karateristik Pasien Karsinoma Ovarium Berdasarkan Gejala Klinis}

Di bawah ini akan disajikan data pasien karsinoma ovarium di RSUD Al-Ihsan Bandung periode 2018-2019 berdsarkan karateristik gejala klinis sebagai berikut :

Tabel 2. Pasien Karsinoma Ovarium di RSUD Al-Ihsan Bandung Periode 2018-2019 Berdasarkan Gejala Klinis

\begin{tabular}{|c|l|c|c|}
\hline Variabel & \multicolumn{1}{|c|}{ Indikator } & $\mathbf{N}$ & $\mathbf{\%}$ \\
\hline Gejala Klinis & $\bullet$ Kista Ovarium & 3 & $13,04 \%$ \\
& - Anemia & 11 & $47,83 \%$ \\
& - Pendarahan Uterus Abnormal (PUA) & 2 & $8,69 \%$ \\
& - Ileus Paralitik & & \\
& - Retensi Urine & 1 & $4,35 \%$ \\
& - Tidak terdiagnosa gejala klinis & 5 & $4,35 \%$ \\
& & $\mathbf{2 3}$ & $\mathbf{1 1 , 7 4 \%}$ \\
\hline
\end{tabular}

Sumber : RS Al-Ihsan Bandung

Berdasarkan tabel 2 di atas menunjukan bahwa jumlah pasien karsinoma ovarium di RSUD Al-Ihsan Bandung yang terdeteksi gejala klinis sebanyak 78,26\%, sedangkan pasien yang tidak mengalami gejala klinis sebesar $21,74 \%$. Gejala klinis paling banyak yaitu anemia sebesar $47,83 \%$, sedangkan paling sedikit yaitu ileus paralitik dan retensi urine sebesar 4,35\%.

\section{Karateristik Pasien Karsinoma Ovarium Berdasarkan Penyakit Penyerta}

Di bawah ini akan disajikan data pasien karsinoma ovarium di RSUD Al-Ihsan Bandung periode 2018-2019 berdsarkan karateristik penyakit penyerta sebagai berikut :

Tabel 3. Pasien Karsinoma Ovarium di RSUD Al-Ihsan Bandung Periode 2018-2019 Berdasarkan Penyakit Penyerta

\begin{tabular}{cccc}
\hline Variabel & \multicolumn{1}{c}{ Indikator } & $\mathbf{N}$ & \% \\
\hline Gejala Penyerta & $\bullet$ Mioma uteri & 2 & $40,00 \%$ \\
& $\bullet$ Gastritis & 2 & $40,00 \%$ \\
& $\bullet$ TBC Paru & 1 & $20,00 \%$ \\
& Total & $\mathbf{5}$ & $\mathbf{1 0 0 \%}$ \\
\hline
\end{tabular}

Sumber : RS Al-Ihsan Bandung

Berdasarkan tabel 3 di atas menunjukan bahwa jumlah pasien karsinoma ovarium di RSUD Al-Ihsan Bandung yang terdeteksi penyakit penyerta paling banyak yaitu mioma uteri dan gastritis sebesar 40,00\%, sedangkan paling sedikit yaitu TBC Paru sebesar 20,00\%.

\section{Karateristik Pasien Karsinoma Ovarium Berdasarkan Komplikasi}

Di bawah ini akan disajikan data pasien karsinoma ovarium di RSUD Al-Ihsan Bandung periode 2018-2019 berdsarkan karateristik komplikasi sebagai berikut :

Tabel 4. Pasien Karsinoma Ovarium di RSUD Al-Ihsan Bandung Periode 2018-2019 Berdasarkan Komplikasi

\begin{tabular}{|c|l|c|c|}
\hline Variabel & \multicolumn{1}{|c|}{ Indikator } & $\mathbf{N}$ & $\mathbf{\%}$ \\
\hline Komplikasi & $\bullet$ Adhesi Matur & 1 & $8,33 \%$ \\
& - Sepsis & 4 & $33,33 \%$ \\
& $\bullet$ Acute Kidney Injury & 2 & $16,67 \%$ \\
& - Efusi Pleura & 4 & $33,33 \%$ \\
& - Congestive Heart Failure (CHF) & 1 & $8,33 \%$ \\
\hline & Total & $\mathbf{1 2}$ & $\mathbf{1 0 0 \%}$ \\
\hline
\end{tabular}

Sumber: RS Al-Ihsan Bandung

Berdasarkan tabel 4 di atas menunjukan bahwa jumlah pasien karsinoma ovarium di RSUD Al-Ihsan Bandung yang terdeteksi komplikasi paling banyak mengalami sepsis dan efusi pleura sebesar 33,33\%, sedangkan paling sedikit adhesi matur dan congestive heart failure (CHF) sebesar 8,33\%. 


\section{Karateristik Pasien Karsinoma Ovarium Berdasarkan Usia}

Di bawah ini akan disajikan data pasien karsinoma ovarium di RSUD Al-Ihsan Bandung periode 2018-2019 berdsarkan karateristik usia sebagai berikut :

Tabel 5. Pasien Karsinoma Ovarium di RS Al-Ihsan Bandung Periode 2018-2019 Berdasarkan Usia

\begin{tabular}{|c|l|c|c|c|}
\hline Variabel & \multicolumn{1}{|c|}{ Indikator } & $\mathbf{N}$ & $\mathbf{\%}$ \\
\hline \multirow{3}{*}{ Usia } & $\bullet<30$ tahun & 5 & $12,50 \%$ \\
& $-30-50$ tahun & 19 & $47,50 \%$ \\
& $-51-70$ tahun & 15 & $37,50 \%$ \\
& $->70$ tahun & 1 & $0,25 \%$ \\
\hline & & $\mathbf{4 0}$ & $\mathbf{1 0 0 \%}$ \\
\hline
\end{tabular}

Sumber : RS Al-Ihsan Bandung

Berdasarkan tabel 5 di atas menunjukan bahwa jumlah pasien karsinoma ovarium di RSUD Al-Ihsan Bandung paling banyak memiliki usia antara 30-50 tahun sebesar 47,50\%, sedangkan paling sedikit memiliki usia di atas 70 tahun sebesar $0,25 \%$.

\section{Pembahasan Pasien Karsinoma Ovarium Berdasarkan Gejala Klinis}

Hasil penelitian menunjukan bahwa jumlah pasien karsinoma ovarium di RSUD Al-Ihsan Bandung yang terdeteksi gejala klinis sebanyak $78,26 \%$, sedangkan pasien yang tidak mengalami gejala klinis sebesar 21,74\%. Gejala klinis pada pasien karsinoma ovarium di RSUD Al-Ihsan Bandung yang terdeteksi diantaranya kista ovarium, anemia, pendarahan uterus abnormal (PUA), ileus paralitik, retensi urine.

Gejala klinis paling banyak yaitu anemia sebesar $47,83 \%$, sedangkan paling sedikit yaitu ileus paralitik dan retensi urine sebesar 4,35\%. Anemia termasuk ke dalam gejala klinis pada pasien karsinoma ovarium. Anemia menandakan kondisi tubuh yang kekurangan sel darah merah. Gejala klinis anemia diakibatkan penyakit karsinoma ovarium yang terus menyebar ke area usus besar. Anemia bisa terjadi karena sel karsinoma yang tubuh dengan cepat sehingga akan terjadi perdarahan di pusat tumor. Kondisi tersebut membuat kadar darah menurun drastis dan menyebabkan anemia. Penelitian yang dilakukan Fatkhiyah (2019) menunjukan dari 26 pasien kista ovarium yaitu faktor risiko anemia sebesar $61,54 \%$.

\section{Pembahasan Pasien Karsinoma Ovarium Berdasarkan Penyakit Penyerta}

Hasil penelitian menunjukan bahwa jumlah pasien karsinoma ovarium di RSUD Al-Ihsan Bandung yang terdeteksi terdeteksi penyakit penyerta paling banyak yaitu mioma uteri dan gastritis sebesar 40,00\%, sedangkan paling sedikit yaitu TBC Paru sebesar 20,00\%.

Mioma uteri termasuk ke dalam penyakit penyerta pada pasien karsinoma ovarium. Mioma uteri merupakan suatu pertumbuhan massa atau daging di dalam rahim atau di luar rahim yang tidak bersifat ganas. Mioma berasal dari sel otot polos yang terdapat di rahim dan pada beberapa kasus juga berasal dari otot polos pembuluh darah rahim. Jumlah dan ukuran mioma bervariasi, terkadang ditemukan satu atau lebih dari satu. Pada umumnya mioma terletak di dinding rahim dan bentuknya menonjol ke rongga endometrium atau permukaan rahim. Mioma dapat berkembang menjadi ganas dan kondisi tersebut dikenal sebagai leiomiosarkoma, namun kemungkinan mioma menjadi ganas cukup kecil. Selain itu mioma dapat menyebabkan komplikasi berupa torsi atau terpuntir, yang dapat menyebabkan gangguan sirkulasi akut sehingga mengakibatkan kematian jaringan. Dampak mioma uteri yang tidak segera ditangani antara lain dapat menyebabkan nyeri perut dan perdarahan abnormal, serta diperkirakan dapat menyebabkan infertilitas. Diantara faktor-faktor risiko yang mempengaruhi mioma uteri antara lain usia, paritas, genetik, fungsi ovarium, ras. Pertumbuhan dan perkembangan mioma uteri dipengaruhi oleh stimulasi hormon estrogen yang disekresikan oleh ovarium. Pada usia reproduksi sekresi hormon estrogen oleh ovarium meningkat, berkurang pada usia klimakterium, dan pada usia menopause hormon estrogen tidak disekresikan lagi oleh ovarium. Oleh karena itu, mioma uteri paling tinggi antara usia 35-50 tahun yaitu mendekati angka 40\%, dan jarang ditemukan pada usia dibawah 20 tahun. Penelitian Pasinggi (2015) menunjukan dari 
data rekam medis ditemukan kasus sebesar mioma uteri sebesar 56,7\% pada kelompok umur 41-50 tahun. ${ }^{7}$

Gastritis termasuk ke dalam penyakit penyerta pada pasien karsinoma ovarium. Gastritis merupakan penyakit pada lambung yang terjadi akibat peradangan dinding lambung. Pada dinding lambung atau lapisan mukosa lambung ini terdapat kelenjar yang menghasilkan asam lambung dan enzim pencernaan yang bernama pepsin. Secara umum, gastritis dibagi menjadi dua jenis yaitu gastritis akut dan kronis. Gastritis akut ketika peradangan pada lapisan lambung terjadi secara tiba-tiba. Gastritis kronis dapat menyebabkan peradangan di lapisan lambung secara perlahan dan dalam waktu yang lama. Peradangan kronis lapisan lambung ini dapat menyebabkan perubahan struktur lapisan lambung dan berisiko berkembang menjadi karsinoma.

\section{Pembahasan Pasien Karsinoma Ovarium Berdasarkan Komplikasi}

Hasil penelitian menunjukan bahwa jumlah pasien karsinoma ovarium di RSUD Al-Ihsan Bandung yang terdeteksi komplikasi paling banyak mengalami sepsis dan efusi pleura sebesar 33,33\%, sedangkan paling sedikit adhesi matur dan CHF sebesar 8,33\%. Komplikasi pada pasien rsinoma ovarium di RSUD Al-Ihsan Bandung yang terdeteksi diantaranya adhesi matur, sepsis, AKI, efusi pleura, dan CHF.

Sepsis termasuk ke dalam gejala komplikasi pada pasien karsinoma ovarium. Sepsis adalah komplikasi berbahaya akibat infeksi. Komplikasi infeksi tersebut dapat menimbulkan tekanan darah turun drastis dan kerusakan pada banyak organ, kedua hal ini dapat menimbulkan kematian. Pasien karsinoma ovarium yang mengalami kemoterapi sering mengalami komplikasi berupa neutropeni febril yang mengakibatkan pasien rentan terhadap infeksi sehingga akibatnya pasien mengalami sepsis. Kemoterapi adalah pengobatan sistemik yang melibatkan penggunaan obat-obat sitotoksik yang biasanya diberikan melalui injeksi maupun oral. Kemoterapi kanker sifatnya tidak selektif, maka kemoterapi juga mengenai sel bukan sel kanker misalnya sum-sum tulang yang disebut myelosuppression yaitu penurunan kemampuan sum-sum tulang menghasilkan sel darah merah, sel darah putih dan trombosit sehingga menimbulkan risiko infeksi (neutropenia) dan pendarahan (trombositopenia). Infeksi yang mungkin terjadi bisa semakin serius bila neutropenia yang terjadi juga semakin lama dan semakin berat. Sebanyak 12,9\% pasien kanker ovarium menderita neutropenia, sehingga perlu perhatian yang intensif karena semakin lama dan berat tingkat neutropenia yang terjadi maka semakin besar dan serius infeksi yang mungkin terjadi. Pasien kanker yang menjalani kemoterapi sering mengalami komplikasi berupa neutropeni febril yang mengakibatkan pasien rentan terhadap infeksi sehingga akibatnya pasien mengalami sepsis, syok septik, dan akhirnya meninggal. ${ }^{8}$

Efusi pleura termasuk ke dalam gejala komplikasi pada pasien karsinoma ovarium. Efusi pleura merupakan penumpukan cairan di antara jaringan yang melapisi paru-paru dan dada. Cairan dapat menumpuk di sekitar paru-paru karena pemompaan jantung yang kurang baik atau karena peradangan. Gejalanya meliputi batuk, nyeri dada yang tajam, atau sesak napas. Perawatannya antara lain pemberian antibiotik, pil air (diuretik), dan pengeluaran cairan. Kanker ovarium dapat menimbulkan komplikasi terutama jika sudah memasuki stadium lanjut salah satunya efusi pleura, hal ini terjadi karena sel-sel kanker sudah menyebar ke organ tubuh lainnya. Penelitian yang dilakukan Rai (2010) menunjukan pasien yang mengalami efusi pleura sebesar 20\%-30\%.

\section{Pembahasan Pasien Karsinoma Ovarium Berdasarkan Usia}

Hasil penelitian menunjukan jumlah pasien karsinoma ovarium di RSUD Al-Ihsan Bandung paling banyak memiliki usia antara 30-50 tahun sebesar 47,50\%, sedangkan paling sedikit memiliki usia di atas 70 tahun sebesar $0,25 \%$.

Karsinoma ovarium dapat menyerang pada umur yang lebih muda dibandingkan dengan karsinoma jenis lainnya, biasanya karsinoma ovarium menyerang wanita mulai dari usia muda berkisar antara berumur sekitar $<30$ tahun. Risiko karsinoma ovarium meningkat seiring dengan bertambahnya usia, karsinoma ovarium meningkat pesat setelah wanita berusia antara 31-50, 
sedangkan usia puncak berkisar pada usia antara 51-70 tahun. Sementara pada usia $>71$ tahun, keganasan karsinoma ovarium secara bertahap menurun. Secara umum, penuaan memungkinkan perpanjangan waktu untuk menyebabkan perubahan genetik secara acak dalam pada permukaan ovarium. ${ }^{5}$ Penelitian yang filakukan Sinaga (2018) menunjukan jumlah kasus kanker ovarium terbanyak terdapat pada kelompok usia antara 36- 50 tahun sebesar 54,20\%. ${ }^{9}$ Penelitian yang dilakukan Arania (2015) menunjukan jumlah kasus kanker ovarium terbanyak terdapat pada kelompok usia antara 31-40 tahun sebesar 54,20\%. ${ }^{10}$ Penelitian yang dilakukan Gea dkk (2016) menunjukan jumlah kasus kanker ovarium terbanyak terdapat pada kelompok usia $\geq 51$ tahun.

\section{Kesimpulan}

Berdasarkan hasil penelitian diperoleh kesimpulan yaitu jumlah pasien karsinoma ovarium di RSUD Al-Ihsan Bandung yang terdeteksi gejala klinis paling banyak yaitu anemia sebesar 47,83\%. Jumlah pasien karsinoma ovarium di RSUD Al-Ihsan Bandung yang terdeteksi terdeteksi penyakit penyerta paling banyak yaitu mioma uteri dan gastritis sebesar $40,00 \%$; Jumlah pasien karsinoma ovarium di RSUD Al-Ihsan Bandung yang terdeteksi komplikasi paling banyak mengalami sepsis dan efusi pleura sebesar 33,33\%; sedangkan Jumlah pasien karsinoma ovarium di RSUD Al-Ihsan Bandung paling banyak memiliki usia antara 30-50 tahun sebesar 47,50\%.

\section{E. Saran}

Berdasarkan hasil penelitian dan pembahasan maka dapat diajukan saran yaitu sebuah rumah sakit diharapkan dapat melengkapi data rekam medis pasien karsinoma ovarium berdasarkan beberapa indikator diantaranya riwayat keluarga, paritas, hormonal, gambaran histopatologi, dejarat dioferensiasi, dan lain sebagainya guna menambah informasi terkait data rekam medis pasien karsinoma ovarium menjadi lebih jelas dan teliti.

Pasien yang terdiagnosa karsinoma ovarium dapat melakukan pemeriksaan setelah merasa gejala klinis, penyakit penyerta, dan komplikasi yang dialami sehingga mendapat pengobatan secepat mungkin.

Diharapkan peneliti selanjutnya dapat menambah berbagai indikator atau faktor risiko yang dapat menyebabkan meningkatnya keganasan karsinoma ovarium. Selain itu dapat melakuakn penelitian di rumah sakit lainnya yang memiliki pusat pelayanan karsinoma di Bandung.

\section{Daftar Pustaka}

[1] World Health Organization. International Agency for Research on Cancer (IARC). 2018. Global Cancer Observatory (GLOBOCAN) : Latest global cancer data: Cancer burden rises to 18.1 million new cases and 9.6 million cancer deaths in 2018.

[2] Badan Pusat Statistik. Angka Harapan Hidup di Indonesia Berdasarkan Provinsi. Jakarta: Badan Pusat Statistik Indoensia; 2019.

[3] Andrijono. Karsinoma Serviks. Edisi 4. Jakarta: Divisi Onkologi Departemen ObstetriGinekologi; Fakultas Kedokteran Universitas Indonesia; 2011.

[4] The International Federation of Gynecology and Obstetrics (FIGO). Ovarian Cancer Staging. 2014; $1-2$.

[5] Prawirohardjo, Sarwono. Ilmu Kandungan. Edisi 2. Cetakan IV. Jakarta: YPB-SP; 2012.

[6] Fatkhiyah, Natiqotul. Faktor Risiko Kejadian Kista Ovarium Pada Wanita Usia Reproduksi Di Rskia Kasih Ibu Kota Tegal. BHAMADA, JITK. STIKes Bhakti Mandala Husada Slawi. 2019 April; Vol. 10, No. 1.

[7] Pasinggi S, Freddy W, Max R. Prevalensi Mioma Uteri Berdasarkan Umur Di RSUP Prof. DR. R. D. Kandou Manado. Jurnal e-Clinic (eCl). Universitas Sam Ratulangi Manado. 2015 Januari-April; Volume 3, Nomor 1.

[8] Rai, I B Ngurah. Efusi Pleura Maligna: Diagnosis Dan Penatalaksanaan Terkini. Universitas 
Udayana. September 2010; Volume 10 Nomor 3.

[9] Sinaga, Lia Rosa Veronika., dkk. Karakteristik Pasien Penderita Kanker Ovarium Yang Rawat Inap di RSUD Dr. Pirngadi Medan Tahun 2012-2016. Wahana Inovasi. Universitas Sari Mutiara Indonesia. Juli-Des 2018; Volume 7 No.2.

[10] Arania, Resti dan Indri Windarwati. Karateristik Pasien Kanker Ovarium di Rumah Sakit Dr. H. Abdul Moeloek Bandar Lampung Tahun 2009-2013. Juke Unila. Univesitas Lampung. Maret 2015; Volume 5 Nomor 9.

[11] Gea, Imanuel T., dkk. Gambaran jenis kanker ovarium di RSUP Prof. Dr. R.D. Kandou Manado periode Januari 2013 - Desember 2015. Jurnal e-Clinic (eCl). Universitas Sam Ratulangi Manado. Juli-Desember 2016; Volume 4, Nomor 2. 